\title{
Vaquitas and gillnets: Mexico's ultimate cetacean conservation challenge
}

\author{
Lorenzo Rojas-Bracho ${ }^{1, *}$, Randall R. Reeves ${ }^{2}$ \\ ${ }^{1}$ Coordinación de Investigación y Conservación de Mamíferos Marinos, Instituto Nacional de Ecología y Cambio Climático, \\ C/o CICESE Carretera Ensenada-Tijuana 3918, Ensenada BC 22860, México \\ ${ }^{2}$ Okapi Wildlife Associates, 27 Chandler Lane, Hudson, Quebec J0P 1H0, Canada
}

\begin{abstract}
There is a high risk that incidental mortality (bycatch) in gillnets will lead to extinction of the vaquita Phocoena sinus, a small porpoise endemic to Mexico's northern Gulf of California. A zoned Biosphere Reserve established in 1993 proved ineffective at slowing the population's decline, and in 2005, a Vaquita Refuge was declared. The Refuge Program included a ban on gillnetting and trawling in certain areas with relatively high densities of vaquitas. However, it was not until 2008, with the introduction of a Species Conservation Action Plan for Vaquita (PACEVaquita), that a comprehensive protection and recovery effort was introduced. Unfortunately, valuable time was lost as officials first needed to bring order to a poorly managed fishery management system. Also, the voluntary nature of fisherman participation and the chronic deficiency of enforcement have limited PACE's effectiveness. Although efforts to implement the plan probably slowed the vaquita's decline, the goal of eliminating gillnets (and thus most vaquita bycatch) by 2012 was not reached. This example shows the difficulty of achieving conservation when the program's rationale centers on the preservation of biodiversity with less emphasis on meeting community aspirations. In fact, not only does the vaquita have no economic value, but the measures taken for its conservation have a negative economic impact and hence are met with hostility, or at best indifference, on the part of fishery authorities and fishing communities. On a more positive note, a light trawl has been field-tested and shown to be efficient at capturing shrimp; such 'vaquita-safe' trawls are suitable for replacing gillnets in the shrimp fishery. Similarly suitable alternative gear needs to be developed urgently for use in the finfish fisheries. Unless entangling nets are removed quickly from the vaquita's habitat, it will soon be too late to save the species, which probably already numbers fewer than 200 animals.
\end{abstract}

KEY WORDS: Phocoena sinus · Bycatch · Artisanal fisheries · Gulf of California

\section{INTRODUCTION}

Since the early 2000s when it became evident that the endemic river dolphin in China's Yangtze River, the baiji Lipotes vexillifer, had quietly slipped into extinction as a result of neglect and complacency (see Turvey 2008), it has often been stated that Mexico's endemic marine porpoise, the vaquita Phocoena sinus, is the world's most endangered cetacean. The available evidence on vaquita numbers, trends, and bycatch levels (Gerrodette et al. 2011, CIRVA 2012) supports this claim. Unlike the case of the baiji, where a variety of threats appear to have conspired to drive the species' rapid decline to extinction, even after warning signs had been evident for decades (Perrin \& Brownell 1989, Zhou et al. 1998, Wang et al. 2006, Turvey et al. 2007, 2010a,b), the vaquita's decline over the last few decades, also accompanied by increasing warning signs and calls for strenuous national and international action (Rojas-Bracho \& 
Taylor 1999, Rojas-Bracho et al. 2006, JaramilloLegorreta et al. 2007), is being driven primarily, and perhaps entirely, by a single cause: incidental mortality in fishing gear.

The purpose of this paper is to describe and evaluate the principal bycatch mitigation measures taken to conserve vaquitas in the years since an earlier comprehensive review which was current through 2005 (Rojas-Bracho et al. 2006). Events related to vaquita conservation since the time of that review, not all of them discussed further here, are listed in Table 1. In considering all of the vaquita conservation activities over the past $6 \mathrm{yr}$, these fall essentially under 2 general categories that are the focus of our review: (1) complete (year-round) area closures to certain types of fishing practices (Refuge Program; see following section) and (2) a relatively complex, multifaceted, comprehensive recovery program (the Species Conservation Action Plan for Vaquita: PACEVaquita). These measures alone have not been adequate, but why is this? As mentioned above and as is made clear in the literature, it is not from a lack of awareness: the vaquita was redlisted by the IUCN as 'Vulnerable' in 1978, 'Endangered' in 1990, and 'Critically Endangered' in 1996. The species has been on the US Endangered Species List since 1985 and on Mexico's equivalent list since 1994. Nor is it from a lack of understanding of what kind of action is needed to stop the vaquita's decline. Over $20 \mathrm{yr}$ ago, Norris (1992, p. 20), a revered cetologist who helped introduce the vaquita to science (Norris \& McFarland 1958), wrote:

The Mexican fishery laws must somehow be made to work, or the species will die out before we come to know it. Even a few paid rangers with a couple of good boats might halt the decline, as would new jobs for fishermen. But will those things happen?

By the mid-1990s, the Mexican government was telling the international community that action was being taken to address the vaquita bycatch issue (Fleischer 1996). In retrospect, however, that action appears to have been half-hearted, at best; any measures that were taken were ineffectual (RojasBracho et al. 2006).

As discussed in detail previously (Rojas-Bracho et al. 2006), the Biosphere Reserve of the Upper Gulf of California and Delta of the Colorado River, declared in 1993, fell far short of what was necessary to address the bycatch threat to vaquitas. In 1996, the Mexican government, through its National Institute of Fisheries (within the Ministry of Environment, Natural Resources and Fisheries), created the International Committee for the Recovery of the Vaquita
(Comité Internacional para la Recuperación de la Vaquita, CIRVA), which included scientists from Europe, Canada, the USA, and Mexico. At its first meeting in January 1997, this committee reviewed and analyzed potential risk factors and concluded that incidental mortality in gillnets represented the greatest immediate threat to the survival of the species. At its second meeting 2 yr later, CIRVA made a series of recommendations, among them that bycatch needed to be reduced to zero as soon as possible and that measures should be taken to relieve or offset the economic hardships imposed on local residents by forced changes in their fishing effort and practices (e.g. compensation schemes, provision of alternative livelihoods, making alternative gear available to allow fishing to continue with little or no risk of vaquita bycatch).

Progress at implementing those initial recommendations was slow and unconvincing, and therefore at its third meeting (in 2004), CIRVA insisted that 'at a minimum,' immediate action be taken to prevent any gillnet fishing within the highest-density portion(s) of the vaquita's range. The committee stressed that such closure alone would not necessarily stop the population decline or guarantee recovery, but as an interim measure it might at least slow the decline and buy time for developing alternative gear and pursuing various socio-economic initiatives (Rojas-Bracho et al. 2006, Rojas-Bracho \& Jaramillo-Legorreta 2009).

\section{VAQUITA PROTECTION PROGRAM IN THE REFUGE AREA, WESTERN UPPER GULF OF CALIFORNIA}

In response to the CIRVA recommendations in 2004, the Ministry of Environment and Natural Resources (SEMARNAT) and the Ministry of Agriculture and Fisheries agreed in September 2005 to establish a 'refuge area for the protection of the vaquita' (DOF 2005a) which would, in time, 'replace' the Biosphere Reserve as the principal tool for protecting vaquitas from bycatch. It was left to SEMARNAT to formulate the accompanying protection measures that would make the refuge operational. Thus, in December of the same year, the 'Vaquita Protection Program in the Refuge Area Located in the Western Portion of the Upper Gulf of California' (referred to hereafter as the Refuge Program) was officially launched (DOF 2005b).

The Refuge Program was premised on the expectation that it would be possible to address the principal factors placing the vaquita at risk of extinction without, at the same time, adversely affecting the welfare 
Table 1. Notable events related to vaquita conservation, 2005-2012 (for earlier years see Rojas-Bracho et al. 2006)

\begin{tabular}{|c|c|}
\hline Date & Event \\
\hline 8 September 2005 & $\begin{array}{l}\text { Publication in the Federal Register of the agreement establishing the area of the Refuge for the } \\
\text { Protection of the Vaquita. The Ministry of Environment and Natural Resources (SEMARNAT) is } \\
\text { instructed to formulate a protection program to accompany designation of the area. }\end{array}$ \\
\hline 29 December 2005 & $\begin{array}{l}\text { Publication in the Federal Register of the Vaquita Protection Program in the Refuge Area Located in } \\
\text { the Western Portion of the Upper Gulf of California. }\end{array}$ \\
\hline 24 February 2007 & $\begin{array}{l}\text { President of Mexico announces the Conservation Program for Endangered Species (Programa de } \\
\text { Conservación de Especies en Riesgo - PROCER) to implement Species Conservation Action Pro- } \\
\text { grams (Programas de Acción para la Conservación de Especies - PACE) for a list of selected species, } \\
\text { including the vaquita among the top } 5 \text {. }\end{array}$ \\
\hline 28 February 2007 & $\begin{array}{l}\text { Letter from IUCN Director-General to President of Mexico requesting that his government take all } \\
\text { necessary measures immediately to ensure that the vaquita, a national treasure of Mexico, does not } \\
\text { go extinct. }\end{array}$ \\
\hline 27 June 2007 & $\begin{array}{l}\text { Governments of Canada, Mexico, and the USA ask the Commission for Environmental Cooperation } \\
\text { (CEC) to formulate a strategy in support of Mexico's efforts to ensure recovery of the vaquita. As a } \\
\text { result, in October } 2008 \text { CEC launched the 'North American Conservation Action Plan Vaquita,' a } \\
\text { cooperative initiative involving scientists, academics, environmental groups, and officials from the } 3 \\
\text { countries. }\end{array}$ \\
\hline 20 August 2008 & PACE-Vaquita is presented to stakeholders. \\
\hline 5-14 October 2008 & $\begin{array}{l}\text { Resolution is adopted at the quadrennial IUCN World Conservation Congress in Barcelona, Spain: } \\
\text { 'Avoiding the extinction of the vaquita porpoise Phocoena sinus.' }\end{array}$ \\
\hline $\begin{array}{l}16 \text { October- } \\
25 \text { November } 2008\end{array}$ & $\begin{array}{l}\text { Vaquita vessel survey. Analyses of data from the survey yielded an abundance estimate of } 245 \\
(\mathrm{CV}=0.73,95 \% \mathrm{CI} 68-884) \text {, i.e. } 57 \% \text { lower than the } 1997 \text { estimate, indicating an average rate of } \\
\text { decline of } 7.6 \% \mathrm{yr}^{-1} \text {. }\end{array}$ \\
\hline July 2009 & $\begin{array}{l}\text { Artisanal fishermen in the northern Gulf of California are the first group of fishermen to produce an } \\
\text { Environmental Impact Assessment (EIA) for fishing in a Protected Natural Area. }\end{array}$ \\
\hline 2009 & $\begin{array}{l}\text { Acoustic monitoring scheme is implemented by the National Institute of Ecology (Instituto Nacional } \\
\text { de Ecología). }\end{array}$ \\
\hline 11 August 2011 & $\begin{array}{l}\text { Armadores Unidos de Puerto Peñasco, S.A. de C.V. (Shipowners United of Puerto Peñasco, SA de CV) } \\
\text { presents an EIA for blue and brown shrimp fishing in the buffer zone of the Biosphere Reserve. }\end{array}$ \\
\hline February 2012 & $\begin{array}{l}\text { Fourth meeting of the International Committee for the Recovery of Vaquita (CIRVA) takes place in } \\
\text { Ensenada. }\end{array}$ \\
\hline June 2012 & $\begin{array}{l}\text { The National Advisory Committee for Responsible Fisheries adopts the amendment to the Official } \\
\text { Mexican Standard, which includes a provision for a } 3 \mathrm{yr} \text { phase-out to remove gillnets in all of the } \\
\text { vaquita's range: } 30 \% \text { in Year 1, } 30 \% \text { in Year 2, and } 40 \% \text { in Year } 3 \text {. However, the amendment with the } \\
\text { relevant provisions to eliminate shrimp gillnets had not been published at the time of writing (Decem- } \\
\text { ber 2012) and will not come into effect until it has been. }\end{array}$ \\
\hline June 2012 & $\begin{array}{l}\text { The vaquita is selected by the Zoological Society of London and the IUCN Species Survival Commis- } \\
\text { sion as one of the world's } 100 \text { most Critically Endangered species. }\end{array}$ \\
\hline
\end{tabular}

of people in the region. In accordance with that premise, the 5 program objectives were as follows:

(1) Promote, define, and establish measures to guide the development of activities aimed at sustainable use of natural resources in the Refuge, consistent with the conservation and recovery of the vaquita. In other words, minimize impacts on vaquitas and maximize the welfare of the people whose livelihoods are based on resources provided by the Refuge Area;

(2) Promote alternative livelihoods and technological development to (a) improve the economic and social well-being of local communities in the region and (b) facilitate the sustainable use of natural resources in the Refuge Area;

(3) Promote biological and socio-economic research;
(4) Promote community participation in the protection and recovery effort through environmental education and outreach;

(5) Establish compliance with regulations applicable to the Refuge and strengthen enforcement.

The Refuge Program specified fishery control actions that included a complete ban on the use of gillnets with mesh sizes greater than 6 inches $(15.25 \mathrm{~cm})$ inside the Refuge and the elimination of fishing with passive or drift nets (these 2 actions were incorporated into the new management program of the Biosphere Reserve). The program defined passive or drift nets as nets that are anchored and are either unattended by the fisherman or are 'soaked' (i.e. remain in the water) for longer than $30 \mathrm{~min}$. In addition to those measures, which were to apply to the entire Refuge Area, all 
commercial fishing with any type of trawl or gillnet was to be banned in 2 'exclusion zones,' one defined as a circle with a 5 mile $(8 \mathrm{~km})$ radius centered at Rocas Consag ('Rocas Consag polygon' in Fig. 1) and the other an arrow-shaped polygon with borders specified by coordinates given in the Federal Register notice ('arrow polygon' in Fig. 1).

Initially, the Refuge Program enjoyed the support (at least on paper and in principle) of all major stakeholder groups, including fisherman cooperatives, local and federal governmental agencies, the commercial fishing industry, and non-governmental organizations. Although the eventual size of the Refuge fell short of what had been proposed by CIRVA, 1264 versus $2593 \mathrm{~km}^{2}$, its total area encompassed the locations of almost $80 \%$ of all confirmed vaquita records over the previous 3 decades (SEMARNAT 2008).

Regardless of how progressive this program might have appeared, the Refuge Area remained essentially unmanaged until 2008 when the Refuge Program was incorporated into the new program called PACE-Vaquita and all fishing was banned within the Refuge Area (see following section).

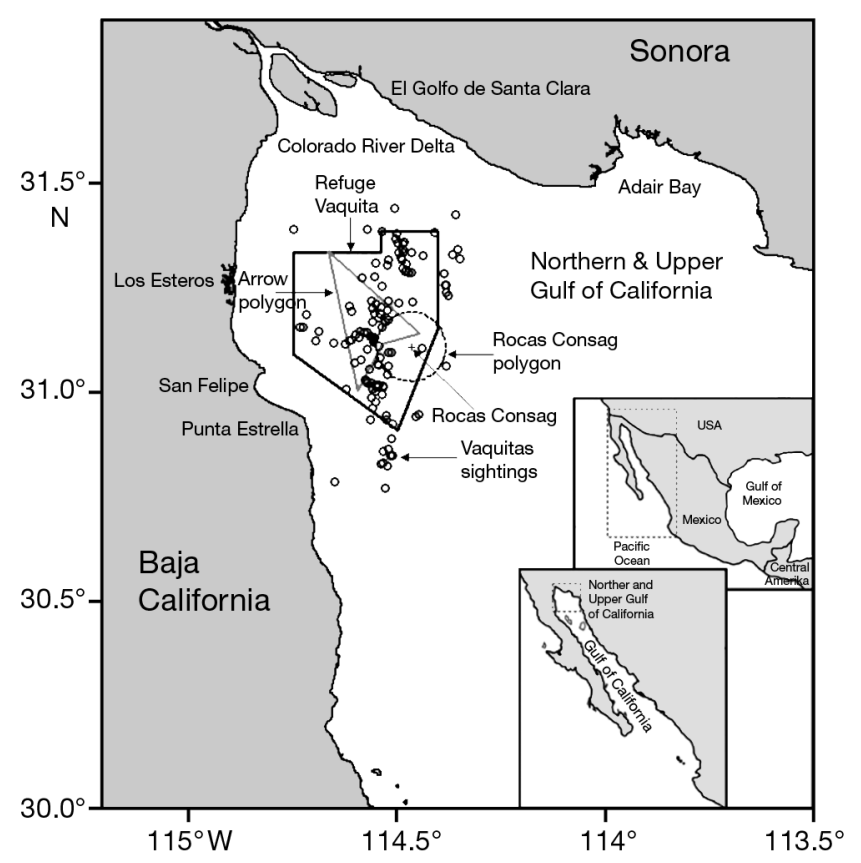

Fig. 1. Positions of vaquita sightings during a 1997 survey (Jaramillo-Legorreta et al. 1999) showing the Vaquita Refuge and the fishing exclusion zones referred to in the Refuge Program (see 'Vaquita protection program in the Refuge Area western Upper Gulf of California'). Out of 141 sightings, 111 (78.7\%) fell within the Refuge, 6 (4.2\%) within the Rocas Consag polygon, and 34 (24\%) within the Arrow polygon

\section{PACE-VAQUITA}

In April 2008, the Mexican government announced what is probably the first-ever comprehensive conservation program intended to eliminate, rather than simply reduce, bycatch of a marine mammal species throughout its range. This program, known as 'Species Conservation Action Plan for the Vaquita: An Integrated Strategy of Management and Sustainable Use of Marine and Coastal Resources in the Upper Gulf of California,' or PACE-Vaquita, represents an attempt to implement all of the main recommendations that had been made by CIRVA through the time of its third meeting in January 2004 (Rojas-Bracho et al. 2006, SEMARNAT 2008). The stated main goal of PACE-Vaquita was little different from that of its predecessor (the Refuge Program), i.e. to conserve the vaquita and enable the species to recover, but it was to do this while also furthering the 'sustainable use' of the region's valuable fishery resources (see SEMARNAT 2008, CIRVA 2012).

The ultimate objective was to eliminate bycatch of vaquitas by removing trammel nets and gillnets from the Refuge, whether by simply eliminating such gear or by replacing it with gear that would not bring the risk of porpoise entanglement. In an initial phase, entangling nets were to be eliminated throughout the Refuge; in a second phase, they were to be eliminated throughout the entire range of the species. Both phases were to be completed by the end of 2012. Besides enforcing the gillnet bans in the Biosphere Reserve and the Vaquita Refuge, multiple strategies were to be pursued to ensure that the forbidden gear was in fact removed. These involved:

(1) Buy-out. This program enabled fishermen to convert to economic activities other than fishing.

(2) Switch-out. Three options were offered as follows: (a) replacing gillnets and trammel nets with alternative fishing gear, (b) providing fishermen with access to fisheries that use methods and gear other than gillnets, and (c) mariculture or aquaculture.

(3) Biodiversity conservation or rent-out. This program compensated fishermen for not fishing within the Refuge.

To clarify, fishermen who were willing to stop fishing were to be compensated through buy-out. Those who expressed a willingness to switch to alternative gear were to be part of switch-out. All of those who agreed not to fish within the Refuge (i.e. abide by the previous ban on the use of gillnets which had proved unenforceable; see Rojas-Bracho et al. 2006) were to be compensated as part of the biodiversity conservation/rent-out component of the overall program. 
Other strategies included (1) encouraging the development of alternative methods of fishing that do not take vaquitas as bycatch, (2) assisting fishermen who have been bought out and wish to start alternative businesses, and (3) a variety of initiatives related to communications, education, and cultural support. For everyone involved, the implementation of PACE-Vaquita has required a difficult learning process (SEMARNAT 2008, Rojas-Bracho \& Fueyo 2010, Ávila-Forcada et al. 2012). Mistakes have been made and not all funds have been invested wisely. As just one example of the difficulties encountered in the early stages of PACE-Vaquita, no pre-existing mechanism was available for giving compensation directly to fishermen who wished to pursue an alternative livelihood. The government therefore had to begin by designing and implementing new programs under which materials could be purchased, workers could be hired, and various start-up costs for new businesses could be met. Such difficulties delayed the recovery program.

Another major challenge facing those charged with implementing PACE-Vaquita was to decide on a procedure for setting the amounts to be offered for buyouts, switch-outs, and rent-outs (Squires 2010). Three options were considered during the negotiations between the government and the fishermen (through their fishing associations). One was for the parties involved to investigate the costs of fishing gear, permits, etc., and then negotiate a mutually agreeable payment schedule. Another option was to conduct an inverse auction in which fishermen would submit sealed bids with the payment levels they were willing to accept, and then the lowest bids would be accepted and applied to everyone. The third option was for the government simply to decide on fixed amounts that it was willing to pay in exchange for gear, permits, etc. (Barlow et al. 2010).

SEMARNAT rejected the first option. It attempted to implement the inverse auction approach, but fishermen colluded to agree on prices in advance among themselves (before the auction took place), and therefore this approach could not function as intended. In the end, the government selected the third option: the offer-to-buy approach. The offers finally made by SEMARNAT were slightly higher than the combined value of permits for shrimp and finfish. For a total buy-out of a fisherman's gear (nets for shrimp and finfish), panga (the fiberglass, outboard-powered boat used for artisanal fishing in the northern Gulf), motor, and more than 3 fishing permits, the payment was 400000 Mexican pesos (over US\$ 33 000); for all fishing gear, panga, motor, and 2 permits, 350000 Mexican pesos (about US\$ 27000 ); and for everything but only one fishing permit, 300000 Mexican pesos (about US\$23000). The amount paid for a switch-out was about US\$27000 and for a rent-out, over US\$ 3400 .

At the time of writing (December 2012), the outcomes of PACE-Vaquita have been modest but hopeful. The buy-out program had purchased 247 pangas (in storage waiting to be recycled) and removed 370 fishing permits. The switch-out program had enabled 230 pangas to be equipped with alternative fishing gear, such as suriperas (a type of throw net) to catch shrimp, while 496 gillnets had been removed and were being stored for eventual shipment to a recycling plant (M. Sau-Cota pers. comm.). Suriperas, however, are difficult to use on a commercial scale. The most significant new development to date was a small or light trawl net (RS-INP-MEX prototype trawl) that had been field-tested and shown to be suitable for replacing gillnets in the shrimp fishery (CIRVA 2012). Once approved by the authorities in Mexico, this light trawl should make it possible to eliminate shrimp gillnet fishing in the northern Gulf, which has long been considered one of the largest sources of vaquita bycatch. The biodiversity conservation/rent-out program has kept 570 pangas from fishing in the Vaquita Refuge. As discussed further below, however, hundreds of pangas have continued to fish in the northern Gulf using gillnets to catch shrimp and finfish.

\section{EVALUATION}

Here we critically evaluate the 2 principal 'tools' used over the last 7 yr to reduce vaquita bycatch.

\section{Refuge Program}

The Refuge Program was in some respects doomed from the outset because its effectiveness depended so heavily on the acceptance and cooperation of fisheries and state government authorities (Rojas-Bracho et al. 2006). The Ministry of Environment transferred US\$ 1 million to the governments of Baja California and Sonora to implement actions within the Refuge. Despite their supposed initial approval of the program, however, the state governments proved unwilling to cooperate and used the available funds for activities unrelated to vaquita conservation (RojasBracho et al. 2006). As just one example, local authorities used some of this funding to purchase new out- 
board engines for fishermen. Given that there was no guidance on how funds transferred by the federal government were to be applied, other than in a manner 'consistent with the conservation and recovery of the vaquita, minimizing negative impacts and maximizing the welfare of the people whose productive activities are developed in the area of the Refuge,' (DOF 2005a, p. 19) it is unsurprising that this funding did nothing to reduce the bycatch threat to the vaquita.

Even if all measures specified in the Refuge Program's mandate had been implemented, it is unlikely that the lofty goal of eliminating risks to vaquitas would have been attained. For example, the gillnet ban applied only to nets with 6 inch $(\sim 15.2 \mathrm{~cm})$ or larger mesh, yet D'Agrosa et al. (2000) estimated annual vaquita mortality to be 13 individuals in shrimp gillnets (generally of 2.5 inch [ 6.35 cm] mesh); 2 in sierra and mackerel nets (2.99 inch [ 7.6 cm] mesh); and 17 in chano nets (3.9-4.3 inch [ 9.9-10.9 cm] mesh). In practice, only gillnets deployed for sharks and rays (6-7.8 inch [ 15.2$19.8 \mathrm{~cm}$ ] mesh) were banned, and it was estimated that 7 vaquitas die annually in those nets (D'Agrosa et al. 2000). Similarly difficult to reconcile is that in spite of CIRVA's recommendation to ban gillnets throughout the vaquita's range, the fishing exclusion zones (described above and shown in Fig. 1) covered only perhaps a quarter of that range.

It must also be acknowledged that the impossibility of enforcing certain key measures meant that in the first 2 or 3 yr of its existence, the Refuge functioned in name only; it was little more than a 'paper park.' For example, the Refuge Program called for the elimination of fishing with passive or drift nets. As mentioned above, these nets were defined as nets that are anchored and are either unattended by the fisherman or are soaked for longer than $30 \mathrm{~min}$. In retrospect, it is difficult to understand how a single regulatory instrument could contain such contradictory elements. Even though gillnets with $<6$ inch mesh were permitted, fishing with passive or drift nets (e.g. gillnets) was not. Also, $30 \mathrm{~min}$ is the minimum soak time for all gillnet fisheries in the northern Gulf (Cudney \& Turk Boyer 1998), which makes the requirement that soak times be no longer than $30 \mathrm{~min}$ somewhat inexplicable. The prospects of achieving effective enforcement of such a complex and disjointed suite of measures would be poor even if fisheries and local governmental authorities were supportive, but in this case they were not. Unfortunately, even with perfect enforcement of a more coherent set of restrictions, the Refuge still would have been insufficient to allow recovery since it contained at any one time only about half of the total vaquita population (Gerrodette \& Rojas-Bracho 2011; see below).

Critics of the Refuge Program (López-Sagástegui et al. 2010, Rodriguez-Quiroz et al. 2010) have judged it in isolation, without considering the PACE-Vaquita framework within which it was eventually set. If there had been no PACE, the claim that government policy was ignoring, or at least not seriously attempting to implement, the most important CIRVA recommendations would be well-founded. However, it can reasonably be argued that the provisions of PACEVaquita (see next section) followed closely, in spirit if not in every detail, the principal CIRVA recommendations, which have been consistently echoed by multilateral bodies such as the International Whaling Commission, scientific societies such as the Society for Marine Mammalogy and the European Cetacean Society, and non-governmental organizations such as the World Wildlife Fund, Natural Resources Defense Council, Cousteau Society, and International Fund for Animal Welfare.

It is important to emphasize that CIRVA has always been clear in its recommendations, beginning with its second meeting in 1999 (see Rojas-Bracho et al. 2006), that steps taken by Mexican authorities towards the complete removal of entangling gear from vaquita habitat could only be seen as interim measures for 'buying time' and that anything short of complete removal could not be expected to stop the population decline or guarantee the species' recovery. There is always a risk that authorities will continue to view the Refuge as the final solution to the vaquita bycatch problem, rather than as just one step (albeit an important one) towards achieving the goal of zero bycatch. It is probably not unusual for interim measures like this one to end up having longer lifetimes than intended or desirable.

\section{PACE-Vaquita}

As mentioned earlier in relation to the Refuge, one of the main obstacles to implementation of PACEVaquita has been the general lack of rigorous fishery management in the northern Gulf. As just one example, neither the fishery authorities nor the fishing communities themselves knew at the outset how many pangas were available or active in the region, how many permits and vessel registration numbers had been issued for a given fishery, and how much netting was available for deployment or in use. 
Therefore, a necessary first step was to bring some order to the governance system. Licenses, permits, and concessions needed to be assigned to individuals and regions so that it would be possible to calculate the costs of program elements and to determine which fishermen should receive a particular type and amount of compensation.

Another challenge was to develop alternative fishing gear that could be promoted to replace gillnets. When PACE-Vaquita was declared in 2008, no actual program of research and development was in place within Mexico to pursue this objective, which in turn meant that there was little basis for proceeding immediately with plans to diversify production and technology. Ideas on how to identify and apply economic incentives, such as certification and labeling of 'sustainable' sea products, were being considered, but many such ideas seemed pointless in the absence of a practical alternative to gillnet capture of shrimp and finfish.

Although Ávila-Forcada et al. (2012, p. 613) presumed that policy makers would 'benefit from understanding the factors driving voluntary participation in PACE-Vaquita,' it is important to emphasize that the voluntary nature of the measures taken has been a major failing of the program, not one of its strengths. Participation in the various program elements (buyout, switch-out, and biodiversity conservation or rent-out) has been non-mandatory (i.e. voluntary) not because it was considered an inherently more effective approach to management but rather because it was the only politically viable option given the strenuous opposition of the fisheries agency to mandatory measures. Furthermore, in light of the fact that PACE-Vaquita has failed to achieve its stated goal of eliminating vaquita bycatch by 2012, it is difficult to see why Ávila-Forcada et al. (2012, p. 613) would conclude that this program might 'encourage other governments with a similar problem to follow suit.'

Voluntary programs may work in some cases where the goal of management is to reduce or relocate, but not eliminate, fishing effort. However, in the northern Gulf of California, and probably many other areas of the world where artisanal fishing is deeply ingrained in the social and economic fabric of coastal communities, there will likely always be a group of dedicated fishermen who are determined to continue fishing no matter what economic alternatives become available to them. Ávila-Forcada et al. (2012) made a number of interesting observations in this regard. According to their findings, fishermen in northern Gulf communities who already possess skills in alternative economic activities are more likely to quit fishing than those with limited education or training. Also, the buy-out option was more appealing to older fishermen who were already close to retirement. As a result, participation in the buy-out scheme essentially stopped once the pool of fishermen close to retirement or possessing skills for other economic activities had given up fishing. No-one enrolled in the buy-out option in response to the government call for applications in 2010. Another factor that may have contributed to the decline in participation in the buy-out program is that those who continue to fish presumably benefit from lessened competition for the resources (shrimp and finfish), making it harder to buy them out on a voluntary basis (Gerrodette \& Rojas-Bracho 2011). We believe that a better management strategy would have been to start with a non-mandatory program providing ample compensation (through rent-out or buy-out) which would be decreased in a stepwise manner to zero, at which point the switch to alternative gear becomes mandatory.

PACE-Vaquita has almost certainly reduced the number of pangas deploying gillnets for shrimp in the northern Gulf, but there is still a long way to go before gillnet fishing has been completely eliminated from the Refuge, and an even longer way before this goal has been achieved in the entire range of the vaquita. Total fishing effort today is greater than it was in the early 1990s when the bycatch rate was estimated to be close to 40 vaquitas $\mathrm{yr}^{-1}$ for just one of the 2 main gillnetting ports in the northern Gulf (D'Agrosa et al. 1995, 2000). Despite the fishing ban in the Refuge, both gillnetting and trawling continue. Not only has enforcement been relaxed since 2009, as mentioned above, but fishing effort per boat actually may have increased considerably since the early 1990s (CIRVA 2012). Fishermen, including those remaining permit holders who are legally allowed to continue gillnet fishing, join the net panels to make them longer, often well over the $200 \mathrm{~m}$ allowed by current regulations. This practice is very difficult to detect at sea, making at-sea enforcement unrealistic. Therefore, enforcement should start at ports where the amount of netting onboard can be monitored at departure.

At the most recent CIRVA meeting in February 2012, Gerrodette used his model (see Gerrodette \& Rojas-Bracho 2011) to estimate the probability of the vaquita population declining to 100 animals, working from the speculative assumptions that about 50 adults would be needed for the population to retain fitness and that about half of the census population would be mature. He considered 2 scenarios, one 
where no conservation measures were taken beyond those in place in 2007 (i.e. before PACE-Vaquita) and the other where the current number of pangas (750) from the 2 main ports (San Felipe and El Golfo de Santa Clara) continued to fish with gillnets. The model indicated that under the first of these scenarios, there would be a $74 \%$ chance of reaching 100 individuals by 2017 . Under the latter scenario (status quo, perfect enforcement), there would be a $19 \%$ chance of reaching the 'point of no return' (i.e. 50 adults) in the next 5 yr (i.e. by 2017; Fig. 2). Since illegal fishing is known to occur within the Refuge (i.e. enforcement is not perfect), this estimate is likely optimistic; in other words, the chance of such a decline is probably even higher than about 1 in 5 . The model also suggested that the measures currently in place have been effective (though not sufficient), because without them, the chance of reaching 100 individuals by 2017 is $74 \%$, or about 3 in 4 . The IWC Scientific Committee also concluded at its annual meeting in 2011 that by reducing gillnet use by almost half, PACE-Vaquita may have slowed, but not stopped, the vaquita's decline (IWC 2012, p. 46).

Gerrodette \& Rojas-Bracho (2011) estimated the probability of success of each of the 'protected area' approaches included in PACE-Vaquita, with success defined as an increase in vaquita abundance after $10 \mathrm{yr}$. According to their analysis, the highest probability of success that could be achieved by the Refuge

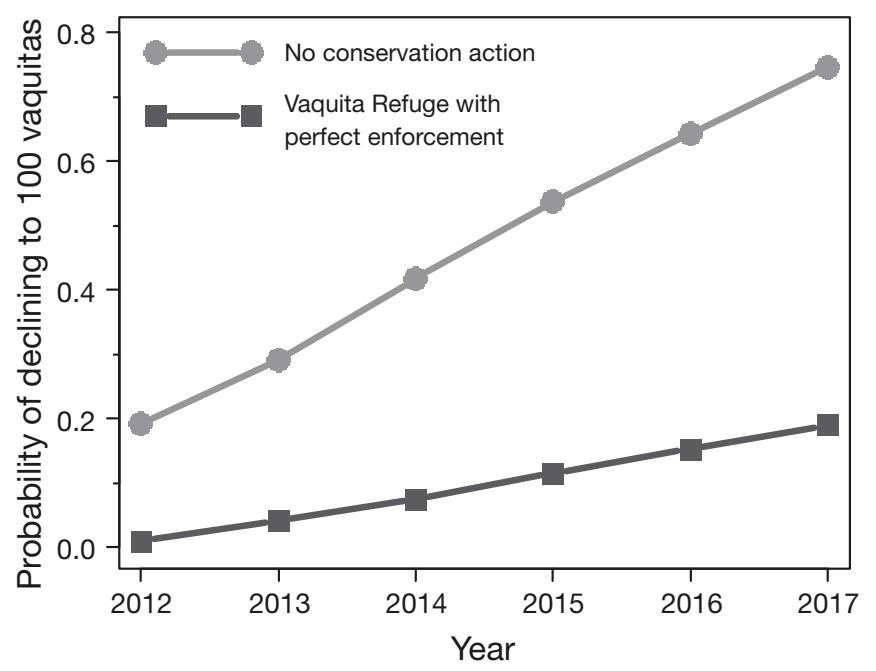

Fig. 2. Probability of reaching 100 or fewer remaining individuals with no conservation action and with full protection in only the Vaquita Refuge. Note that enforcement within the Refuge is assumed to be perfect and the probability shown by the Vaquita Refuge line is optimistic. Used with permission from T. Gerrodette, who prepared the figure for CIRVA (2012) as presently configured, assuming perfect compliance (i.e. no gillnet fishing occurs), was 0.08 . Another option in which the size of the Refuge was substantially increased but still fell short of encompassing the entire range of vaquitas would have an estimated probability of success of 0.35 ; in other words, it would have been 2 times more likely to fail than to succeed. A probability of success greater than 0.99 (virtual certainty) would be realized only if the protected area were large enough and sufficiently well enforced to eliminate vaquita bycatch entirely. Needless to say, these probabilities would be reduced if compliance (or enforcement) were delayed or incomplete.

Although Mexican authorities made a strong effort from 2008 to 2010 to enforce the ban on gillnetting in the Refuge (J. M. Gracía-Caudillo pers. comm., L. Rojas-Bracho pers. obs.), that effort has since waned. Based on aerial surveillance, the average number of pangas detected fishing illegally in the Refuge was 29 in October to December 2009 and 28 in October to December 2010, but it increased back to 2007 levels of around 85 in 2011 (J. M. Gracía-Caudillo pers. comm.). In February 2012, evidence from 3 different sources - aerial surveys, satellite images of fishing boats, and the loss of moorings and acoustic equipment presumably as a result of being fouled in gearwas presented to CIRVA, showing that a substantial amount of illegal fishing had continued to occur inside the Refuge (CIRVA 2012). In the late spring of 2012 , it was reported that 87 boats were fishing there illegally (Jaramillo-Legorreta et al. 2012, IWC 2013).

\section{CONCLUSIONS}

A number of factors have frustrated efforts to stop the decline and allow recovery of the vaquita over the last 2 decades. Among these are (1) confusion regarding alternative hypotheses for what has caused the species' decline (e.g. see Rojas-Bracho \& Taylor 1999, Rojas-Bracho et al. 2006); (2) the failure of place-based conservation measures in the absence of effective enforcement (i.e. both the Biosphere Reserve and the Vaquita Refuge); (3) the need to integrate social and economic considerations into conservation remedies (PACE-Vaquita); (4) the reluctance and inefficiency of government ministries, especially the Mexican fisheries agency CONAPESCA, in moving forward with solutions; (5) the lack of a credible, well-organized fishery management regime in the northern Gulf; and (6) the slow pace of development of alternative fishing gear. 
It has become increasingly evident that bycatch of vaquitas must not just be reduced, but stopped, if we are going to prevent extinction and allow the species to begin a recovery. The only way to reach the zero bycatch goal is by eliminating gillnets from the waters where these porpoises occur. It is also plainly evident, however, that the northern Gulf cannot be closed to fishing, even with continuation and expansion of the compensatory socio-economic opportunities provided to fishermen and fishing communities under PACEVaquita. Therefore, a 2-pronged strategy is a sine qua non: (1) enforced closure of all of the vaquita's range to fishing with gillnets (and other entangling nets) and (2) provision of means for fishermen to pursue their livelihoods without putting vaquitas at risk.

In terms of enforcement, there is no way to avoid the need for a total ban on gillnets throughout the vaquita's range. When some areas are open and others are not, and especially when the boundaries of closed areas are based on geographical abstractions (i.e. lines drawn across open-sea areas on maps) rather than obvious physical discontinuities (e.g. land masses or fixed features of the seascape), enforcement becomes an even greater challenge than it normally would be. When gillnets of certain mesh sizes are allowed and others are banned, or certain soak times are allowed in one area but not in others, this simply further complicates the task of enforcement. More than US\$ 5 million have been spent on at-sea surveillance since 2008. Not only has the surveillance effort not been effective, but it is also not sustainable. Optimal cost-effectiveness of enforcement efforts can only be achieved if all gillnets are banned and monitoring is carried out at the fishing ports of embarkation. In such a scenario, any netting found in the water would be removed, confiscated, and destroyed.

An important lesson from the vaquita case is that no recovery program such as PACE-Vaquita can be successful in the absence of a credible fishery management system that includes, at a minimum, good records of fishing effort (e.g. numbers and types of boats, kinds and quantities of fishing gear, numbers of trips per boat). A major achievement of PACEVaquita is that it has forced CONAPESCA to begin the process of individualizing multi-boat permits so that each of them covers only 1 vessel. The agency can now regulate the granting of fishing permits and monitor license holders, their boats, gear, and authorized landing sites, and each boat carries a chip containing all of the relevant data (Barlow et al. 2010, Rojas-Bracho and Fueyo 2010). This should have the effect of reducing the number of illegal fishermen operating in the northern Gulf. If a proper fishery management system had been in place from the outset, PACE-Vaquita's implementation would have been smoother and faster.

Conservation or recovery strategies in the marine realm that depend on a 'protected area' approach (including time-area fishery closures) often face the familiar problem of getting multiple agencies to cooperate, or at least co-exist peaceably. In most instances, the fisheries and environment ministries are inherently in conflict because of their respective mandates to promote exploitation (fisheries) versus protection (environment) (see Reeves 2000). In the present case, the Mexican government has had to mount an intensive effort through PACE-Vaquita, both economically and politically, to cope with this inter-agency conflict. A particular obstacle has been the difficulty of convincing fisheries authorities (and other influential stakeholders) that bycatch, rather than pollution or environmental changes caused by damming of the Colorado River in the USA, is the main threat to vaquitas (Rojas-Bracho \& Taylor 1999, Rojas-Bracho et al. 2006; see American Society of Mammalogists: www.mammalsociety.org/uploads/ committee_files/vaquita \%20letter\%202-en.pdf).

There is also the problem that vaquitas are of no practical value, whether realized or potential. No governmental agency can be expected to support closure of a profitable fishery unless the political costs of not closing it exceed the benefits of maintaining it. To date, the costs of not banning gillnetting to protect vaquitas have been calculated only in terms of 'biodiversity loss,' and this makes it very difficult for politicians and bureaucrats to justify a ban. It is interesting to compare this situation to one where a threatened animal species or population has realized or potential economic value from tourism, or it has cultural, spiritual, or nutritional (subsistence) importance to local people. As McClanahan et al. (2006) demonstrated in the case of coral reefs, management regimes designed to meet community aspirations tend to achieve greater compliance and subsequent conservation success than regimes designed primarily or solely for biodiversity conservation.

More than 20 yr after Norris's urgent call for serious efforts to save the vaquita, where are we today? Attempted fishery closures, buy-out schemes, and socioeconomic programs have not been enough, and there is reason to believe that the porpoise population is in worse shape now than it was in the early 1990s. Today, the most promising immediate option is for the shrimp fishery to switch from gillnets to small, lightweight trawls, which have been shown to catch commercial quantities of brown shrimp Panaeus cali- 
forniensis at night and blue shrimp P. stylirostris during the day without posing any threat to vaquitas. The availability of these trawls should make it possible to eliminate shrimp gillnets and move significantly closer to the zero bycatch goal. Mexican authorities must ensure that artisanal shrimp fishing vessels are converted immediately from using gillnets to using small trawls (as recommended by CIRVA 2012). This requires amendment of the Mexican Official Standard 002 (NOM-002-PESC-1993) which regulates shrimp fishing. At the time of writing (December 2012), the National Advisory Committee for Responsible Fisheries had adopted the amendment, including a provision for a 3 yr phase-out to remove gillnets in all of the vaquita's range. However, the amendment with the relevant provisions to eliminate shrimp gillnets had not been published and therefore was not yet operative. Meanwhile, the urgent need remains of finding, and getting the fishing fleet to adopt, a similarly effective alternative means of catching finfish.

Gormley et al. (2012) recently demonstrated a substantial increase in survival rates of Hector's dolphins Cephalorhynchus hectori in New Zealand, where protected areas had been used as the primary tool for addressing the bycatch threat. Theirs is the first direct evidence that marine protected areas can work as intended to stop and even reverse declines of endangered cetaceans, but only if (1) they are large enough, (2) they are in the right place, (3) they effectively manage key threats, (4) they remove impacts rather than simply displace them to other areas, and (5) no new threats are added.

The immediate path forward in the case of the vaquita must include the following: (1) funding to manufacture the new trawls, (2) funding and support for the transition by fishermen from gillnets to the trawls, (3) a serious and sustained commitment to enforcement, (4) monitoring the operation of the new trawl fishery to ensure that it does not have any serious, unforeseen environmental consequences, and (5) identifying, or if necessary developing, and making available alternative 'vaquita-safe' gear for finfish fisheries.

There are many ways to explain the failure of conservation efforts on behalf of the vaquita, just as there were in the case of the baiji. Neither the baiji nor the vaquita has any economic value, even as objects of tourism. The environments of these 2 range-restricted species - Yangtze River for the baiji, northern Gulf of California for the vaquita - are used intensively by people (but only for fishing in the northern Gulf and not for industry and transportation as in the Yangtze) who, although not actively hostile towards cetaceans, are largely indifferent towards them. The deaths of the animals are at once incidental and inconsequential when set against the daily challenges faced by most people living along either the Yangtze River or the northern Gulf of California. In contrast to the baiji situation, however, where the true cause or causes of the species' rapid decline were never clearly known and the international community failed to comprehend the seriousness of its condition until the species was gone (Reeves \& Gales 2006, Turvey 2008), we know exactly why the vaquita is disappearing, we know what needs to be done to arrest the decline, and, importantly, there are signs of real progress in finding a practical way of doing it. Yet the challenge remains of moving quickly and decisively before it is too late.

\section{NOTE ADDED IN PROOF}

In early 2013 the new Government of Mexico established a 17-member Comisión Asesora de la Presidencia de México para la Recuperación de la Vaquita (Advisory Commission of the Presidency of Mexico for the Recovery of the Vaquita). The first meeting of the Commission took place on 5 February 2013 in Mexico City. The Commission consists of representatives of major Mexican non-governmental organizations and key government agencies (including Fisheries and Environment), 1 Senator (Senador), 1 member of Congress (Diputado), and 4 scientists (including both authors of the present study). At its first meeting, the Commission recommended that 'transition' work (conversion from shrimp gillnetting to fishing for shrimp with the new light trawls) proceed on a fast-track schedule, that development and trialing of 'vaquita-safe' finfish gear be assigned high priority, and that enforcement efforts be strengthened to improve compliance with existing regulations. The Commission also made a commitment to help identify the financial resources needed to compensate fishermen, above and beyond the compensatory elements of PACE, for income lost as a result of vaquita protection measures.

Acknowledgements. We are grateful to G. Cárdenas for help with the figures, L. Fueyo, D.M. Avila, M. Sau, and O. Ramírez (CONANP) for providing information on PACEVaquita, and J.M. García-Caudillo for providing information on panga surveys. We also appreciate the support received over the years from the US Marine Mammal Commission, which has allowed R.R.R. to be involved in vaquita conservation efforts, including participation in CIRVA and coauthorship of this paper. Finally, we appreciate the thoughtful, constructive reviews of the manuscript by T. Ragen and 2 other reviewers. 


\section{LITERATURE CITED}

Ávila-Forcada S, Martínez-Cruz A, Muñoz-Piña C (2012) Conservation of vaquita marina in the northern Gulf of California. Mar Policy 36:613-622

Barlow J, Rojas-Bracho L, Muñoz Piña C, Mesnick S (2010) Conservation of the vaquita in the northern Gulf of California, Mexico. In: Grafton RQ, Hilborn R, Squires D, Tait M, Williams $M$ (eds) Handbook of marine fisheries conservation and management. Oxford University Press, New York, NY, p 205-214

CIRVA (Comité Internacional para la Recuperación de la Vaquita) (2012) Report of the 4th meeting of the International Committee for the Recovery of the Vaquita. Available at www.iucn-csg.org/wp-content/uploads/2010/03/Reportof-the-Fourth-Meeting-of-the-International-Committeefor-the-Recovery-of-Vaquita.pdf

Cudney R, Turk-Boyer PJ (1998) Pescando entre mareas del Alto Golfo de California. Centro Intercultural de Estudios de Desiertos y Océanos, CEDO, Puerto Peñasco

D'Agrosa C, Vidal O, Graham WC (1995) Mortality of the vaquita (Phocoena sinus) in gillnet fisheries during 1993-94. In: Bjørge A, Donovan GP (eds) Biology of the phocoenids. Rep Int Whal Comm (Spec Issue 16). IWC, Cambridge, p 282-291

D'Agrosa C, Lennert CE, Vidal O (2000) Vaquita by-catch in Mexico's artisanal gillnets fisheries: driving a small population to extinction. Conserv Biol 14:1110-1119

DOF (Diario Oficial de la Federación) (2005a) Acuerdo mediante el cual se establece el área de refugio para la protección de la vaquita (Phocoena sinus). Diario Oficial de la Federación (DOF) México, 8 de septiembre del 2005, Primera Sección, Mexico City, p 6-7

DOF (2005b) Programa de protección de la vaquita dentro del área de refugio ubicada en la porción occidental del Alto Golfo de California. Diario Oficial de la Federación (DOF) México, 29 de diciembre del 2005, Primera Sección, Mexico City, p 19-24

Fleischer L (1996) Mexico progress report on cetacean research, April 1994 to March 1995. Rep Int Whal Comm 46:262-265

Gerrodette T, Rojas-Bracho L (2011) Estimating the success of protected areas for the vaquita, Phocoena sinus. Mar Mamm Sci 27:E101-E125

Gerrodette T, Taylor BL, Swift R, Rankin S, Jaramillo-Legorreta A, Rojas-Bracho L (2011) A combined visual and acoustic estimate of 2008 abundance, and change in abundance since 1997, for the vaquita, Phocoena sinus. Mar Mamm Sci 27:E79-E100

Gormley AM, Slooten E, Dawson S, Barker RJ, Rayment W, du Fresne S, Bräger S (2012) First evidence that marine protected areas can work for marine mammals. J Appl Ecol 49: $474-480$

IWC (International Whaling Commission) (2012) Report of the Scientific Committee. J Cetacean Res Manag 13(Suppl): $1-73$

IWC (2013) Report of the Scientific Committee. J Cetacean Res Manag 14(Suppl):1-86

- Jaramillo-Legorreta AM, Rojas-Bracho L, Gerrodette T (1999) A new abundance estimate for vaquitas: first step for recovery. Mar Mamm Sci 15:957-973

Jaramillo-Legorreta A, Rojas-Bracho L, Brownell RL Jr, Read AJ, Reeves RR, Ralls K, Taylor BL (2007) Saving the vaquita: immediate action, not more data. Conserv Biol 21: 1653-1655

Jaramillo-Legorreta AM, Cardenas-Hinojosa G, Nieto-Garcia E, Rojas-Bracho L (2012) First sampling period of the acoustic monitoring scheme of vaquita (Phocoena sinus) population trend. Scientific Committee document SC/64/ SM19. International Whaling Commission, Cambridge.
http://iwc.int/index.php?cID=2695\&cType=document

López-Sagástegui C, Róbles A, Hernández M, Espinosa R (2010) Dialogo y construcción de acuerdos en el Alto Golfo de California: el caso de Alto Golfo Sustentable. Caso elaborado por el Centro de Colaboración Cívica para el Programa de Creación de capacidades para el manejo efectivo de las Áreas Marinas Protegidas en el Golfo de California. Available at www.colaboracioncivica.org/images/stories/ descargas/publicaciones/agscasoestudio.pdf

> McClanahan TR, Marnane MJ, Cinner JE, Kiene WE (2006) A comparison of marine protected areas and alternative approaches to coral-reef management. Curr Biol 16:1408-1413

Norris KS (1992) Dolphins in crisis. Natl Geogr Mag 182:2-35

- Norris KS, McFarland WN (1958) A new harbor porpoise of the genus Phocoena from the Gulf of California. J Mammal 39: 22-39

Perrin WF, Brownell RL Jr (eds) (1989) Report of the workshop. In: Perrin WF, Brownell RL Jr, Zhou K, Liu J (eds) Biology and conservation of the river dolphins. Occasional Paper 3. IUCN Species Survival Commission, Gland, p 1-22

Reeves RR (2000) The value of sanctuaries, parks, and reserves (protected areas) as tools for conserving marine mammals. Final report for contract T74465385. Marine Mammal Commission, Bethesda, MD

> Reeves RR, Gales NJ (2006) Realities of baiji conservation. Conserv Biol 20:626-628

Rodríguez-Quiroz G, Aragón-Noriega EA, ValenzuelaQuiñónez W, Esparza-Leal HM (2010) Artisanal fisheries in the conservation zones of the Upper Gulf of California. Pesca artesanal en las zonas de conservación del Alto Golfo de California. Rev Biol Mar Oceanogr 45:89-98

Rojas-Bracho L, Fueyo L (2010) Helping the vaquita to recover-conservation and management actions by Mexico. J Am Cetacean Soc 39:7-10

Rojas-Bracho L, Jaramillo-Legorreta A (2009) Vaquita Phocoena sinus. In: Perrin WF, Würsig B, Thewissen JGM (eds) Encyclopedia of marine mammals. Elsevier, Amsterdam, p 1196-1200

Rojas-Bracho L, Taylor B (1999) Risk factors affecting the vaquita (Phocoena sinus). Mar Mamm Sci 15:974-989

Rojas-Bracho L, Reeves RR, Jaramillo-Legorreta A (2006) Conservation of the vaquita Phocoena sinus. Mammal Rev 36: $179-216$

SEMARNAT (Ministry of Environment and Natural Resources) (2008) Programa de acción para la conservación de la especie (PACE): Vaquita (Phocoena sinus). Estrategia integral para el manejo sustentable de los recursos marinos y costeros en el Alto Golfo de California. Available at www. iucn-csg.org/wp-content/uploads/2010/03/PACE-vaquitaenglish.pdf

> Squires D (2010) Fisheries buybacks: a review and guidelines. Fish Fish 11:366-387

Turvey ST (2008) Witness to extinction: how we failed to save the Yangtze River dolphin. Oxford University Press, Oxford

> Turvey ST, Pitman RL, Taylor BL, Barlow J and others (2007) First human-caused extinction of a cetacean species? Biol Lett 3:537-540

Turvey ST, Barrett LA, Yujiang H, Lei Z and others (2010a) Rapidly shifting baselines in Yangtze fishing communities and local memory of extinct species. Conserv Biol 24:778-787

Turvey ST, Leigh A, Barrett LA, Hart T and others (2010b) Spatial and temporal extinction dynamics in a freshwater cetacean. Proc R Soc Lond B Biol Sci 277:3139-3147

- Wang D, Zhang X, Wang K, Wei Z, Würsig B, Braulik GT, Ellis $\mathrm{S}$ (2006) Conservation of the baiji: no simple solution. Conserv Biol 20:623-625

Zhou K, Sun J, Gao A, Würsig B (1998) Baiji (Lipotes vexillifer) in the lower Yangtze River: movements, numbers, threats and conservation. Aquat Mamm 24:123-132 